\title{
OPERATIONAL RISK ASSESSMENT OF AN ENGLISH ACADEMY IN YOGYAKARTA
}

\author{
Anastasia Filiana Ismawati \\ Ciputra University
}

\begin{abstract}
This research was conducted for the risk assessment on the operational activities in order to assist PT XYZ to support social entrepreneurship and managing the operational activities which leads to the goals of the firm. The use of Enterprise Risk Management (ERM) can help the organization to manage the risks holistically using the integrated methods. This research focused on the risk assessment in PT XYZ, especially for its operating, and provided a strategy of improvement from the existing risks. The methodology used in this research is a case study with triangulation of sources as the tool to conduct the data analysis. The informants of this research are the Operational Manager of PT XYZ and five teachers. The data was obtained by conducting interviews and there were six operational risks found which would be best to respond and to manage as soon as possible for minimizing the risks. The result of this research is to hope that PT XYZ shall be able to manage the risks by using the ERM methodology in order to have the business in the long run and to be successfully competing in the market.
\end{abstract}

Keywords: risk assessment, operational risks, strategy of improvement, social entrepreneurship

\section{INTRODUCTION}

Social entrepreneurship can be optimal if it has several criteria, including having parties who have transformative power (Widiastuti, 2011). The application of social entrepreneurship needs to be balanced with controls within the organization so that the implementation of operational activities can still run effectively and support organizational goals.

The risk management is applied to fulfill the market demand and to ensure that the ethics of business continuity for the company are proven. The purpose of applying management risk in a firm is to make it effective when the firm also applies the internal control. The support from all parties of the organization is influential to control the risks and to reach the goals of the firm.

\footnotetext{
*Corresponding Author.

e-mail: anastasia.filiana@gmail.com
}

PT XYZ is engaged in a field of educational service, especially English courses. This firm is in collaboration with one of the academies in Spain, named WE. PT XYZ was founded to fulfill the needs of Spanish people in learning English and interest in Indonesian cross cultural by delivering the classes online. WE itself decided to be in collaboration with PT $\mathrm{XYZ}$ due to the demand of the consumers on either native English speakers or bilingual ones. Bringing Indonesian culture to the international sphere is one form of PT XYZ's contribution to the development of Indonesian cultures.

How the business progresses sometimes does not go well as the system planned. Early risk management is necessary to do so that the operating process works effectively and efficiently. To comprehend the risks can help the employer to discover causes and effects of the 
Anastasia Filiana Ismawati / Operational Risk Assessment of an English Academy in

Yogyakarta /JEE, Vol. 9, No. 2, September 2020, pp 49-56

risks for the importance of operational purposes. The support from all parties is helpful to analyze the existing risks.

One of the risks possibly to arise in the operational activities is the difference between the working hour in Indonesia and Spain which can be five to six-hour difference. The time difference causes the operational activities to start from 7 PM (GMT+7) to 4 AM (GMT+7). Tchankova (2002:292) stated that the operational risks were divided to two components which are namely the risk of operational failure and the risk of potential strategy.

Social entrepreneurship is a social value creation that is formed by working with other people or community organizations involved in social innovation which usually implies an economic activity (Hulgard, 2010). The collaboration between PT XYZ and a language institution in Spain that provides language education by carrying online language learning and teaching about crossculture is one of the company's strategies in implementing creative efforts in creating social and business value relationships for the creation of greater economic and social value.

It takes a precise internal control in order to manage a complex business process. A precise internal control can support the purpose of that entity such as the reliability of financial report, the effectivity and efficiency of the operating as well as the law obedience and regulations applied. The application of ERM can provide a continuous development for an industry which can be seen from risk identification, measurement and management that affect the increase of economy efficiency.

The application of ERM enables a firm to provide some information financially and nonfinancially about the risk profile and it functions as a commitment signal for risk manage- ment (Hoyt \& Liebenberg, 2011). PT XYZ has not yet applied a risk assessment to manage the operational activities. The application of ERM can assist the firm in order to gain some knowledge about the existing operational risks so that it is possible for the firm to identify the factors of the risks and how to cope with them.

\section{METHOD}

This is a qualitative research using the methodology of case study. A case-study research can provide more effective evidence to depict complex events or situations under certain contexts as well as factors and the ongoing process which take place at a certain place and time where the event is happening (Basuki, 2016; Gumanti et al., 2016).

Method of collecting data in this research was obtained through interviews in which all questions were aimed to discover the information of operational activities in PT XYZ as well as the risk management in the operational activities taken from the employer and the employees. The triangulation of sources method was used to collect the data by holding a profound interview on the manager and the employees at PT XYZ. The result of the interview is made into a form of transcript and the researcher shall analyze and describe it. Then, an analysis on the result of the interview about risk management is made into a form of risk level matrix in order to see the main risk element regarding the possibility of this to happen and the impact of the risk. To decide the level of the risk can be seen from the impact and the frequency of how much the risk are likely to happen.

The informants for this research are six people who are the manager and the employees 
(teachers). In Table 1 are the profiles of the six informants. The selection of informants has the criteria of having direct involvement in operational activities and having contributed to the company for at least 1 year.

Table 1 Profiles of Informants

\begin{tabular}{|c|l|l|l|}
\hline Name & \multicolumn{1}{|c|}{ Sex } & \multicolumn{1}{|c|}{ Position } & $\begin{array}{c}\text { Length of } \\
\text { work }\end{array}$ \\
\hline A & Female & Manager & 4 years \\
\hline B & Female & Teacher & 3 years \\
\hline C & Female & Teacher & 3 years \\
\hline D & Female & Teacher & 1 year \\
\hline E & Female & Teacher & 1 year \\
\hline F & Male & Teacher & 1 year \\
\hline
\end{tabular}

\section{RESULTS}

In this research, the researcher presents the findings about the risks based on the interviews with the manager and the employees of PT XYZ related to the operational risks. Each of the interviewees has been working for at least one year at PT XYZ and possesses English fluency as a very background to become an educator. Data collection was carried out through interviews and carried out for each informant 3 times to reconfirm the statements of the informants.

COSO (2004) stated that by applying the risk management, a firm could align the risks which the firm receives and the strategy to be executed; to increase the responses from the firm towards the decision of whether a risk shall be rejected, reduced, distributed or received; to eliminate unexpected events and loss in operational activities; to identify and to manage all risks happened at the firm; to be active towards all opportunities; and to increase the capital distribution in the firm for the operational activities. This research values the risks by observing the level of the likelihood and the impact of the risks.

In relation to the operational risks in PT $\mathrm{XYZ}$, there are six of them successfully identified:

Table 2 Risk Level

\begin{tabular}{|c|c|c|c|c|c|}
\hline \multirow{2}{*}{ Ranking } & \multirow{2}{*}{ Risk categories } & \multicolumn{2}{|c|}{ Average } & \multirow{2}{*}{ Total } & \multirow{2}{*}{ Risk level } \\
\hline & & $\mathrm{L}$ & $\mathrm{I}$ & & \\
\hline 1 & Risk of using the learning methods & 3 & 5 & 15 & High risk \\
\hline 2 & Risk of learning documentation & 3 & 3 & 9 & Medium risk \\
\hline 3 & Risk of limited internet access & 2 & 4 & 8 & Medium risk \\
\hline 4 & Risk of lesson planning & 2 & 3 & 6 & Medium risk \\
\hline 5 & Risk of limited teaching aids & 2 & 3 & 5 & Medium risk \\
\hline 6 & Risk of working-hour division & 1 & 1 & 1 & Low risk \\
\hline
\end{tabular}

\section{Risk of using the Learning Methods}

The risk of using the learning methods is at the highest on likelihood in comparison to other risks and it is classified as a high-risk level. This risk appears due to the different capabilities of the students in perceiving the lessons as well as the changing of their moods which cause the educators to find difficulties in keeping the learning pace. The management has to follow this up in order to manage this risk into an acceptable level for ensuring that the goals of the firm are still reachable. In this context, the risk of using the learning methods becomes one of the dynamic risks which can appear from a certain situation changing (Hanafi, 2006). The firm can respond towards the risk by distributing the risk for not only using one single platform only (Skype, in this case), but also using other platforms such as schoology, kahoot, mentimeter and others, so that the boredom during the learning will be bearable.

Table 3 Extract from the Interviews Related to the Use of Learning Methods

I1: It is too much to handle, actually, because I found it difficult sometimes for myself. However, I would just repeat the material three times approximately 
Anastasia Filiana Ismawati / Operational Risk Assessment of an English Academy in

Yogyakarta /JEE, Vol. 9, No. 2, September 2020, pp 49-56

until the students can understand it and I would usually review the material in the upcoming meeting.

I2: Trying to ensure the idea of the material which the students are supposed to understand is well-received, oftentimes using games or stories to create another atmosphere besides studying.

\section{Risk of Learning Documentation}

The risk of learning documentation is at the second place among the other risks which have been successfully identified and measured. The risk of learning documentation is considered as an unacceptable risk and the firm has to do something about it. One of the problems related to the learning documentation is that there were times when the employees neglected the updates of the logbook which basically tell about the student's progress. The use of logbook to monitor the learning documentation has been done to minimize the risk.

Table 4 Extract from the Interviews Related to the Learning Documentation

I1: We use the logbook to know how far the students are in understanding the materials given. If they have mastered the materials, we can move on to the next ones. If it's the contrary, we will be repeating with a different approach. Thus, logbooks really help.

I2: Sometimes the teachers are not being on time to update the logbooks so it'll trouble the preparation of the next material. They sometimes wrote incorrect information also (the dates and which lesson plan given). Being on time is necessary in order to keep an eye on the learning progress.

\section{Risk of Limited Internet Access}

The risk of limited internet access is at the third place. The operational activities at the firm are being executed in Indonesia without ignoring the fact that the clients do live in Spain which makes the learning methods become online. For those reasons, the internet access remains a big risk. The difference of the internet speed in each country is counted as a challenge for the firm to maintain the service quality. A firm can get a higher risk if they do not pay attention to the time horizon related to the possibly upcoming risks and have no contingency plans (James, 2003). In this case, the firm can respond towards the risk by distributing the risk to be in collaboration with other internet providers. Thus, there will be a back-up if a network disruption happens.

Table 5 Extract from the Interviews Related to the Limited Internet Access

I1: The staff cannot do anything if it comes to the internet access. However, if something happens to the application (Skype), I usually command a troubleshooting myself and if it doesn't work, I'll use other teacher's laptop as long as it is not being used at that moment.

I2: I usually inform the students when there's a network problem then I'll try to give them a call three more times. If it still doesn't work, the management usually reschedules the classes.

\section{Risk of Lesson Planning}

Based on the identified risks, an analysis shall be conducted to rank each of the operational risks at PT XYZ. From the six risks which have been identified, the fourth place with medium risk is the risk of lesson planning. The risk of lesson planning appears due to the circumstance where the lesson does not go as planned. Thus, it creates a severe impact as in the student's progress remains at the same place. The understanding of operational risks especially on lesson planning will enable the firm to perform a great corporate governance. (Paape and Spekle, 2012). The firm shall be able to reduce the chance of the risk by providing a training program for its employees or to improve the Standard Operating Procedure (SOP). 
Table 6 Extract from the Interviews Related to the Lesson Planning

I1: Logbook is used to ensure that the lesson plans are well-delivered up to a certain point by providing the information needed to ensure that the students have understood the materials as expected.

I2: If the lesson plans do not exist, we'll be just having a conversational class while it's not supposed to be done that way. By having the lesson plans, the learning activity can focus more on the curriculum.

\section{Risk of Limited Teaching Aids}

Limited teaching aids can affect the teaching and learning process which results in a stagnant situation. By not having them, the learning process becomes less appealing and it can cause complaints coming from the clients. It is necessary to handle the risk to reduce the impact and the likelihood of risks to occure (Wiryono, 2008). The response to prevent the risk of limited teaching aids is to reject the risk so that the firm is able to provide the teaching aids in order to create an optimal learning as well as to lessen the clients' complaints.

Table 7 Extract from the Interviews Related to the Limited Tracing Aids

I1: We've got great facilities which can support the teaching and learning process at its best.

I2: When the teaching aids are impossible to hold (due to some technical problems), the classes become merely conversational. The learning materials are likely to be delivered but not as good as they should be.

\section{Risk of Working-Hour Division}

The risk of working-hour division is at the lowest rank among the other risks and it's classified as a low-risk level. Based on the interview, the risk of working-hour division can appear if there's an employee being absent which causes the other teachers to be respon- sible at delivering the classes in order to make the operational activities go smoothly. The response towards the risk to take for reducing the risk of working-hour division is to receive the risk. The firm can perform normally due to the decided shares of allowance in the employee's salary.

Table 8 Extract from the Interviews Related to the Working-Hour Division

I1: If we need to reschedule a class, the academy will be on it by using the available space in the teachers' schedules so that there is no need to ask them work overtime.

I2: It depends. Usually the workload of the (absent) colleague will be distributed equally and there has been any significant issue so far.

I3: It depends on the reason of being absent. If it's an illness or urgency, I wouldn't mind. It's a part of my job as an employee and a colleague.

\section{DISCUSSION}

One of the main elements in social entrepreneurship is having an innovative way of ensuring that businesses will have access to the resources needed as long as they can create social value (Sofia, 2015). PT XYZ sees an opportunity in forming a new business model that is beneficial to empowering the surrounding community and involves various aspects of development and practice in the field. One of the control tools in operational activities for business continuity can be done through risk assessment.

One of the challenges experienced by the management of the firm, especially the one in operational sector, is the risk assessment and risk management in order to minimize the risks. The evaluation of Enterprise Risk Management is done through some phases, which begins by analyzing the condition of the internal environment in the business entity and setting the firm 
goals. Then, identifying events, assessment on risks, communication and information effectively towards the firm staff should be done as well as the supervision of the ongoing risk management (Dewi, 2010).

There are three types of risks which the firm should pay attention to: high risk, medium risk and low risk (Haryani, 2018). Risks considered as high risk are the ones which the firm should prioritize to manage and they are considered urgent. These risks have got a severe impact on the other operational activities. The risks classified as medium risk are for the firm to deal with as soon as successfully managing the ones at a high-risk level. The impact of medium-risk level is not too significant but it still has to be managed in order not to create a potential opportunity for them to be high risk. The risks classified as low risk come the least in priority for the firm to manage. These risks have got a smaller impact and rarely appear in the firm. However, the firm should not set them aside due to the possibility of them being at high-risk level.

PT XYZ has never done a risk assessment seen from its likelihood and its impact. By applying ERM, hopefully PT XYZ can discover issues or sources of risks in order to prevent them to happen. There are six risks collected from the operational activities at PT XYZ: risk of using the learning methods, risk of learning documentation, risk of limited internet access, risk of lesson planning, risk of limited teaching aids and risk of working-hour division. The risk of using the learning methods is classified as a high-risk level. The risks of learning documentation, limited internet access, lesson planning and limited teaching aids are classified as a medium-risk level. Last but not least, the risk of working-hour division is classified as a low-risk level.
The management and determination of the risk responses are for the firm to conduct for anticipating the risks to be at the high-risk level. The responses can be done by distributing, receiving, rejecting or reducing the risks. There is a need of preparation to overcome events which can potentially cause risks, such as providing back-up facilities or sources for the firm to possess as well as emergency plans which shall to be performed effectively.

\section{REFERENCES}

Basuki. (2016). Metode Penelitian Akuntansi dan Manajemen Berbasis Studi Kasus. Surabaya: Airlangga University Press.

COSO. (2004). Enterprise Risk ManagementIntegrated Framework Executive. Summary. http://www.coso.org/.

Deloitte \& Touche L. P. P., e. a. (2012). Risk Assessment in Practice. COSO.

Dewi, Irra Chrisyanti \& Herachwati, Nuri. (2010). Analisis Dampak Kepemimpinan Transaksional dan Transformasional terhadap Pembelajaran Organisasi pada PT Bangun Satya Wacana Surabaya. Jurnal Manajemen dan Teori Terapan, 3(3), 1-15.

Fitri, S. D., Setyowati, D. L., \& Duma, K. (2019). Implementasi Manajemen Risiko Berdasarkan ISO 31000:2009 pada Program Perawatan Mesin di Area Workshop PT X. Faletehan Health Journal, 6(1), 16-24.

Gumanti, T. A., Yunidar, \& Syahruddin. (2016). Metode Penelitian Pendidikan. Jakarta: Mitra Wacana Media.

Hanafi, M. M. (2006). Manajemen Risiko. Yogyakarta: UPP STIM YKPN.

Haryani, Dwi Septi. (2018). Evaluasi Peran Enterprise Risk Management dalam Upaya Pengelolaan Risiko Operasional Pada Usaha 
Percetakan Kedai Digital di Tanjungpinang. Jurnal Manajerial dan Bisnis Tanjungpinang, 2(01), 15-27.

Hoyt, Robert E \& Liebenberg, Andre P. (2011). The Value of Enterprise Risk Management. Journal of Risk and Insurance, 78(4).

Hulgard, Lars. (2010). Discourses of Social Entrepreneurship-Variation of The Same Theme? EMES European Research Network.

James C. Hayton. (2003). Strategic Human Capital Management in SMEs: An Empirical Study of Entrepreneurial Performance. Human Resource Management, 42(4), p. 375-391.

Lam, J. (2003). Enterprise Risk Management. United States of America: Wiley.

Marlina, M. A. E., \& Maichal. (2017). Accounting Active Learning dan Hasil Pembelajarannya: Studi Kasus pada Universitas Berbasis Kewirausahaan. AKRUAL: Jurnal Akuntansi, 9(01), 82-94.

Miles, M. B., \& Huberman, M. A. (1994). Qualitative Data Analysis, Second Edition. California: SAGE Publications Inc.

New Integrated ERM Framework. New Jersey: John Wiley \& Sons, Inc.
Paape, Leen \& spekle. Ronald F. (2012). The Adoption and Design of Enterprise Risk Management Practices: An Empirical Study. European Accounting Review, 21(3), 533-564.

Proviti. (2006). Guide to Enterprise Risk Management.

Sofia, Irma Paramita. (2015). Konstruksi Model Kewirausahaan Sosial (Social Entrepreneurship). Sebagai Gagasan Inovasi Sosial Bagi Pembangunan Perekonomian. Jurnal Universitas Pembangunan Jaya, 2(2). 223.

Sugiyono. (2009). Memahami Penelitian Kualitatif. Bandung: Alfabeta

Tchankova, Lubka. Risk Identification - Basic Stage in Risk Management. (2002). Environmental Management and Health, 13(3), 290-297.

Widiastuti, Ratna \& Margaretha, Meily (2011) Socio Entrepreneurship: Tinjauan Teori dan Perannya bagi Masyarakat. Jurnal Manajemen, 11 (1), pp. 1-8.

Wiryono, S. K. \& Suharto. Analisis Risiko Operasional di PT TELKOM dengan Pendekatan Metode ERM. (2008). Jurnal Manajemen Teknologi, 7(01), 58-90. 
Anastasia Filiana Ismawati / Operational Risk Assessment of an English Academy in Yogyakarta /JEE, Vol. 9, No. 2, September 2020, pp 49-56 